\title{
Increased ocean carbon export in the Sargasso Sea linked to climate variability is countered by its enhanced mesopelagic attenuation
}

\author{
M. W. Lomas ${ }^{1}$, D. K. Steinberg ${ }^{2}$, T. Dickey ${ }^{3}$, C. A. Carlson $^{4}$, N. B. Nelson ${ }^{5}$, R. H. Condon ${ }^{1}$, and N. R. Bates ${ }^{1}$ \\ ${ }^{1}$ Bermuda Institute of Ocean Sciences, 17 Biological Lane, St. George's, GE01, Bermuda \\ ${ }^{2}$ Virginia Institute of Marine Science, The College of William and Mary, Chesapeake Bay Hall S206, P.O. Box 1346, \\ Gloucester Pt., VA 23062-1346, USA \\ ${ }^{3}$ Ocean Physics Laboratory and Department of Geography, Ocean Physics Laboratory, EH 1629, University of California, \\ Santa Barbara, CA 93106-3060, USA \\ ${ }^{4}$ Department of Ecology, Evolution and Marine Biology, Marine Biotechnology Building, Room 3147, University of \\ California, Santa Barbara, CA 93106-3060, USA \\ ${ }^{5}$ Institute for Computational Earth System Science, Mail Code 3060, University of California, Santa Barbara, \\ CA 93106-3060, USA
}

Received: 27 August 2009 - Published in Biogeosciences Discuss.: 6 October 2009

Revised: 14 December 2009 - Accepted: 15 December 2009 - Published: 5 January 2010

\begin{abstract}
Photosynthetic $\mathrm{CO}_{2}$ uptake by oceanic phytoplankton and subsequent export of particulate organic carbon (POC) to the ocean interior comprises a globally significant biological carbon pump, controlled in part by the composition of the planktonic community. The strength and efficiency of this pump depends upon the balance of particle production in the euphotic zone and remineralization of those particles in the mesopelagic (defined here as depths between 150 and $300 \mathrm{~m}$ ), but how these processes respond to climatedriven changes in the physical environment is not completely understood. In the Sargasso Sea, from 1996-2007, we have observed a decade-long $>50 \%$ increase in euphotic zone integrated autotrophic biomass (estimated from chlorophyll TChl- $a$ ), prokaryotic phytoplankton, primary production and shallow $(150 \mathrm{~m})$ POC export coinciding with a shift in the mean phase of the winter North Atlantic Oscillation (NAO) from consistently positive to neutral but variable. During this same period mesopelagic POC flux attenuation has doubled such that carbon sequestration below $300 \mathrm{~m}$, the maximum winter/spring ventilation depth, has not changed. The increased mesopelagic POC attenuation appears mediated by changes in plankton community composition and metabolic activity in both the euphotic and mesopelagic zones. These changes are counter to extant hypotheses regarding interrelationships between phytoplankton community composition, productivity and carbon export, and have significant im-
\end{abstract}

Correspondence to: M. W. Lomas (michael.lomas@bios.edu) pacts on how the Sargasso Sea ecosystem, at least, is modeled. Moreover, these time-series observations suggest that processes in the euphotic zone and mesopelagic are tightly coupled and should be considered together in future research.

\section{Introduction}

Marine phytoplankton are responsible for approximately $50 \%$ of global primary production (Field et al., 1998), most of which occurs in the oligotrophic ocean gyres, and so even small variations in primary production can have significant impacts on the global oceanic carbon cycle. A fraction of this production is sequestered in the ocean interior through both active and passive settling of particulate material and has been termed the biological carbon pump (Volk and Hoffert, 1985). Globally, the oceanic biological carbon pump sequesters $\sim 2.5 \mathrm{Pg} \mathrm{Cy}^{-1}$ from the surface ocean (e.g., Gruber and Sarmiento, 2002). The strength and efficiency of the biological carbon pump in a given oceanic regime are controlled by a complex array of processes involving the production of particulate organic carbon (POC) in the euphotic zone and its remineralization with depth through the mesopelagic zone (Buesseler et al., 2007; Neuer et al., 2002) (here defined as 150-300 m). Phytoplankton diversity plays a central, but debated, role in POC production and carbon export efficiency. For example, mineral-ballasted phytoplankton like diatoms and coccolithophores are thought to disproportionately enhance the strength and efficiency of carbon export due to their mineral frustules which enhance sinking rates

Published by Copernicus Publications on behalf of the European Geosciences Union. 
thereby reducing contact time in the upper ocean (e.g., Armstrong et al., 2002; Michaels and Silver, 1988). In contrast, it has been suggested that all phytoplankton, even picoplankton, contribute to carbon export in direct proportion to their contributions to primary production (Richardson and Jackson, 2007). A key point in reconciling these two disparate hypotheses is that the mechanisms of export differ; i.e., export of mineral phytoplankton is likely dominated by gravitational sinking while export of picoplankton are packaged into larger particles via grazing and/or aggregation. Resolving these two hypotheses is important to predicting future carbon sequestration in the oceans given that the oligotrophic gyres are dominated by non-mineral ballasted phytoplankton and account for $\sim 60 \%$ of global carbon export.

In addition to complexities of phytoplankton diversity on the spatial scale, temporal variability needs to be considered given the non-steady state conditions characterized by the present-day increase of atmospheric $\mathrm{CO}_{2}$ and accompanying increase of global ocean temperatures and stratification. Oligotrophic gyres previously considered "static" on a year-over-year basis, due largely to a lack of data, are now recognized to display substantial temporal variability (e.g., Karl et al., 2002; Maranon et al., 2003). Behrenfeld et al. (2006) show that global ocean net primary production and phytoplankton biomass (from 1997-2006), driven largely by changes within the oligotrophic gyres, decreased from 1999-2006 in response to increased water column stratification; evaluated as an increase in the multivariate El niño index. In contrast, or perhaps exemplifying the confounding temporal/spatial interactions, Karl et al. (2001) show that primary production and phytoplankton biomass in the North Pacific Subtropical Gyre, at the Hawaii Ocean Time-series and VERTEX sites, increased over the past three decades in response to a hypothesized increase in stratification, which was linked to a shift in the phase of the Pacific Decadal Oscillation (PDO). Moreover, just within the two decades of the Hawaii Ocean Time-series (HOT) program, Corno et al. (2007) have observed a continued trend for increasing primary production that also has been linked to the ENSO/PDO and changes in stratification. Corno et al. (2007) also have observed that phytoplankton biomass (TChl- $a$ ) and primary production increased in concert suggesting the increased primary production was due to increasing biomass rather than changes in the physiology of the resident autotrophs. This increase in primary production and biomass occurred with a shift from larger eukaryotes to smaller prokaryotes, but data are lacking for this site to evaluate consequent changes in the biological carbon pump on the same three decade timescale. Recent modeling activities have attempted to capture these trends in euphotic zone integrated primary production at both time-series sites (Saba et al., 2010) with limited success, thus highlighting the need to gain better understanding of processes below the depths which satellites can see into the ocean.
For the past two decades biogeochemical measurements have been made in the northwestern Sargasso Sea as part of the Bermuda Atlantic Time-series Study (BATS; Steinberg et al., 2001). The Sargasso Sea, on an annual basis, is a net sink (net air-to-sea flux) for $\mathrm{CO}_{2}$ due to the strength of biological carbon sink during the winter/spring period which offsets the strong $\mathrm{CO}_{2}$ source in the summer (Bates, 2007). Using the Sargasso Sea as a natural laboratory, we examined temporal variability of phytoplankton abundance, primary production, carbon export and its attenuation below the euphotic zone to evaluate the strength and efficiency of the winter/spring biological carbon pump in response to a shift in the phase of the dominant climate mode for the North Atlantic, the North Atlantic Oscillation.

\section{Materials and methods}

\subsection{Sampling scheme and biogeochemical stock and rate measurements}

Monthly Hydrographic and biogeochemical measurements have been collected at the BATS site since October 1988. Starting in January 1990, biweekly measurements have been made during the winter/spring bloom period (January to April) for all measurements except POC gravitational flux, which are measured just once monthly. This sampling scheme results in up to 4-6 data points during each annual winter/spring bloom period, the time period considered in this retrospective analysis. The BATS data are available from the Bermuda Institute of Ocean Sciences/Bermuda Atlantic Time-series Study web page (http://bats.bios.edu/). Specific details and information for all of the methods can be found on the web page as well under BATS Information/Methods, but a brief description of each method relevant to this particular work is given below.

Irradiance data were collected as part of the Bermuda BioOptics Project (BBOP). Underwater irradiance data were collected using the Multi-channel Environmental Radiometer (MER) from 1992 to 1999 and the Satlantic Profiling Multichannel Radiometer (SPMR) from 2000 to 2007. PAR was computed using wavelength integration of irradiance $\left(E_{\mathrm{d}}\right)$ spectrum using Planck's law to estimate spectral quantum flux from energy. The 1\% PAR depth was interpolated from valid surface PAR and vertical profiles.

Dissolved oxygen is sampled before all other measurements to avoid compromising the samples by atmospheric gas exchange. Oxygen samples are drawn into individual BOD flasks and analyzed using an automated Winkler titration method (Williams and Jenkinson, 1982). In 1993 the original system was replaced with a UV endpoint detector system that substantially increased system precision.

Samples for $\mathrm{NO}_{3}^{-}, \mathrm{NO}_{2}^{-}$and $\mathrm{PO}_{4}^{-3}$ were gravity filtered through $0.8 \mu \mathrm{m}$ Nuclepore polycarbonate filters using in-line polycarbonate filter holders, then frozen $\left(-20^{\circ} \mathrm{C}\right)$ in HDPE 
bottles until analysis (Dore et al., 1996). Tests of frozen versus refrigerated samples have indicated no significant difference between storage methods (Dore et al., 1996). Nitrite concentrations were subtracted from combined $\mathrm{NO}_{3}^{-} / \mathrm{NO}_{2}^{-}$ concentrations to estimate $\mathrm{NO}_{3}^{-}$concentrations. Nutrient samples prior to $\sim 2003$ were analyzed on a modified Technicon Autoanalyzer and samples post $\sim 2003$ were analyzed on an Alpkem Flow Solution IV; both instrumental setups have comparable sensitivity and method detection limits. During every sample run, several commercially available certified standards, Ocean Scientific International and Wako Chemical, were analyzed to maintain the generation of high quality data, as well as "standard water" from $3000 \mathrm{~m}$ which serves as an internal standard.

Bulk phytoplankton biomass (TChl- $a$ ) and specific accessory pigments were analyzed by HPLC (from 1990-2004 using the method of Bidigare (1991), and from 2005-2007 using the method of Van Heukelem and Thomas (2001). For the sample volumes filtered, both methods have a detection limit of $\sim 1 \mathrm{ng}$ and compare favorably with each other. Whole water samples $(4 \mathrm{~L})$ were filtered onto $47 \mathrm{~mm} \mathrm{GF} / \mathrm{F}$ filters using polycarbonate in-line filter holders under a low vacuum pressure $(<100 \mathrm{~mm} \mathrm{Hg})$ and then stored in liquid nitrogen until analysis on shore. In the laboratory, pigments were extracted by placing the filter in $5 \mathrm{ml}$ of $100 \%$ acetone (the retention volume of the filter is approximately $0.8 \mathrm{ml}$ resulting in a final acetone concentration of $\sim 90 \%$ and, a final extraction volume of $5.8 \mathrm{ml}$ ) and allowed to extract overnight at $-20^{\circ} \mathrm{C}$. Samples $(1 \mathrm{ml})$ were eluted on a reverse-phase $\mathrm{C} 18$ column $(250 \times 4.6 \mathrm{~mm}, 5 \mu \mathrm{m}$ particle size, ODS-2 Spherisorb C18 column) using a three-step mobile phase program. The mobile phases are as follows: (a) Eluent A - 80:20 v:v, methanol: $0.5 \mathrm{M}$ ammonium acetate, pH 7.2; (b) Eluent B - 90:10 v:v, acetonitrile: water, and; (c) Eluent $\mathrm{C}$ - ethyl acetate. Sample peak identities were determined based upon retention times of pure standards and algal extracts of known pigment composition. The HPLC system was calibrated with commercially obtained pigment standards where the concentrations were determined spectrophotometrically in the appropriate solvent using recommended extinction coefficients (e.g., Bidigare, 1991). Sample peaks were quantified using a response factor generated for each pure pigment standard.

HPLC pigment concentrations were converted to relative taxonomic phytoplankton distributions using the equations of Letelier et al. (1993), which have been shown to accurately reflect phytoplankton populations, as determined by electron microscopy, at all depths in this region of the Sargasso Sea (Anderson et al., 1996). The taxonomic groups and signature pigments used are as follows: Cyanobacteria (excluding Prochlorophytes, i.e., Synechococcus), zeaxanthin; Haptophytes, 19'-hexanoyloxyfucoxanthin; and Diatoms, fucoxanthin. These are the only groups that showed significant changes in absolute biomass and/or relative abun- dance and therefore are the only groups considered in this manuscript. Samples for picoplankton enumeration have been collected on each core BATS cruise from October 2001 to present. Samples are collected from 9 depths between 0 and $140 \mathrm{~m}$, fixed with paraformaldehyde $(0.5 \%$ final concentration), stored at $\sim 4{ }^{\circ} \mathrm{C}$ for $1-2 \mathrm{~h}$, before long term storage in liquid nitrogen. Samples were analyzed on a Becton Dickinson (formerly Cytopeia Inc.) Influx cytometer using a $488 \mathrm{~nm}$ blue excitation laser, appropriate Chl$a(692 \pm 20 \mathrm{~nm})$ and phycoerythrin $(580 \pm 15 \mathrm{~nm})$ bandpass filters, and was calibrated daily with $0.53 \mu \mathrm{m}$ and $2.88 \mu \mathrm{m}$ fluorescent microbeads (Spherotech Inc. Libertyville, Illinois, USA). Each sample was run for 4-6 $\min (\sim 0.2-0.3 \mathrm{ml}$ total volume analyzed), with log-amplified Chl- $a$ and phycoerythrin fluorescence, and forward and right-angle scatter signals recorded. Data files were analyzed from twodimensional scatter plots based on red or orange fluorescence and characteristic light scattering properties (e.g., DuRand and Olson, 1996) using FCS Express 3.0 (DeNovo Software Inc. Los Angeles, California, USA). Pico-autotrophs were identified as either Synechococcus or Prochlorococcus based upon cell size and the presence or absence of phycoerythrin, respectively. Based upon these gating criteria, the number of cells in each identified population was enumerated and converted to cell abundances by the volume-analyzed method (Sieracki et al., 1993). Precision of triplicate samples was

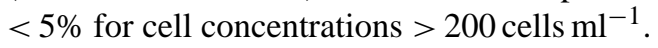

Zooplankton were collected using a vertically integrated (0-200 m) oblique tow (Madin et al., 2001). After collection, samples were fixed with buffered formaldehyde ( $\sim \%)$, split using a Folsom Splitter, with one-half split sieved through sequential nitex screens to separate specific size fractions. Size-fractionated samples, were washed onto a smaller nitex screen, rinsed with buffered milli-Q water to remove salt and dried to constant weight.

Rates of primary production, $250 \mathrm{ml}$ incubations, were calculated from the autotrophic incorporation of $\mathrm{H}^{14} \mathrm{CO}_{3}^{-}$into autotrophs (i.e., particles $>0.7 \mu \mathrm{m}$ ) using an assumed ratio of total inorganic carbon present to radiocarbon added. For each sample depth, $\mathrm{H}^{14} \mathrm{CO}_{3}^{-}$was added to triplicate light bottles, a single dark bottle and a single $T_{0}$ bottle with a sample for total added activity removed from the $T_{0}$ bottle. Samples were incubated in situ from local dawn to dusk $(\sim 12 \mathrm{~h})$ at the depths from which they were originally collected. Rates of primary production were calculated from the mean light bottle value corrected for the dark bottle value, and integrated to a depth of $140 \mathrm{~m}$.

Bacterial production (BP) was measured using $\left[{ }^{3} \mathrm{H}-\right.$ methyl] thymidine incorporation during a $2-3 \mathrm{~h}$ dark incubation at in situ temperatures. A median thymidine conversion factor of $1.63 \times 10^{18}$ cells mol $^{-1}$ thymidine and cellspecific C-biomass value of $4.5 \mathrm{fg} \mathrm{C}^{-1} \mathrm{cell}^{-1}$ (Carlson et al., 1996) were used to convert thymidine incorporation rates to carbon-based bacterial production estimates using standard equations (Carlson and Ducklow, 1996). Bacterial Carbon 
Demand (BCD) was estimated by dividing bacterial productivity by a bacterial growth efficiency of 0.14 (Carlson and Ducklow, 1996). Prior to 1998, only several years of data are available (Carlson et al., 1996).

The POC sinking flux from the euphotic zone was quantified using surface-tethered particle interceptor traps (Knauer et al., 1979). Traps were deployed for 3-4 days and filled with a brine solution $\left(50 \mathrm{~g} \mathrm{NaCl} \mathrm{L}^{-1}\right.$ above ambient seawater) containing formaldehyde $\left(0.7 \% \mathrm{v} \mathrm{v}^{-1}\right.$, final concentration). No accounting was made for dissolution of particulate material post collection in the trap, which can be a highly variable fraction that based upon literature data averages $\sim 30 \%$ for carbon (Antia, 2005). After manual removal of swimmers, samples were dried to constant weight at $65^{\circ} \mathrm{C}$, fumed overnight in a desiccator saturated with $\mathrm{HCl}$ fumes, re-dried at $65^{\circ} \mathrm{C}$, and then analyzed using a Control Equipment Model 240XA CHN elemental analyzer (Knap et al., 1997). Carbon and nitrogen fluxes were calculated from the mass of material captured in the trap, its surface area and deployment length. $\triangle \mathrm{POC}$ was calculated as the difference in average POC fluxes at 150 and $300 \mathrm{~m}$. Mesopelagic transfer efficiency was calculated as the ratio of POC fluxes at $300 \mathrm{~m} / 150 \mathrm{~m}$ (Buesseler et al., 2007).

\subsection{Data processing}

In this study the entire focus is on the winter/spring period that is defined as the period from 1st January to 30th April in a given year. Generally there are 4-6 sampling efforts during this period each year and each is considered independently in estimates of biogeochemical changes over time based upon the observation that the de-correlation timescale is roughly 15 days in this region of the Sargasso Sea (Dickey et al., 2001). All profile data are integrated to $140 \mathrm{~m}$ which is $\sim 0.1 \%$ PAR level (e.g., Siegel et al., 2001) and the deepest sampling depth that does not exceed the $150 \mathrm{~m}$ sediment trap depth. Where data are integrated over different depth ranges, this is stated. NAO data were downloaded from NCAR's Climate Analysis Section (http://www.cgd.ucar.edu/cas/jhurrell/indices.html).

Macronutrients consumed during the course of each winter/spring bloom period were calculated as the difference between measured concentrations averaged for November/December (before bloom initiation) and April/May (after bloom termination). November/December were chosen as the pre-bloom months as $\mathrm{N}_{2}$-fixation is past its summer maximum (Orcutt et al., 2001) and mixed layer depths (MLDs) were shallower than the euphotic zone. Mesoscale eddies not withstanding, the balance between nutrient inputs, consumption and remineralization should be relatively stable and therefore a reasonable estimate of the pre-winter/spring bloom nutrient pool can be estimated. May was chosen as the post-bloom month as MLDs have shoaled to less than the euphotic zone depth and measured nutrient concentrations represent what was consumed, in a net sense, with minimal bias associated with new $\mathrm{N}$ inputs by $\mathrm{N}_{2}$-fixation that increase throughout the summer. The density surface on which nutrient concentrations were estimated for this calculation was the $\sigma_{\theta}=26.27-26.32 \mathrm{~kg} \mathrm{~m}^{-3}$. This isopycnal range was chosen because it is shallower than the core of the $18^{\circ} \mathrm{C}$ mode water, and therefore minimally impacted by non-local productivity and nutrient consumption (Palter et al., 2005). These isopycnals, during months of active convection and mixed layer depths $>100 \mathrm{~m}$, are the source waters for nutrients in the winter/spring bloom.

Total community metabolism was estimated from the calculation of apparent oxygen utilization (AOU). AOU calculations are compromised by deep mixing and therefore are usually calculated on an annual basis, after seasonal stratification has occurred. In this manuscript, data collected on cruises between when the seasonal mixed layer shallowed to $<200 \mathrm{~m}$ and the end of April were used and therefore do not include any heterotrophic metabolism during the period of deepest convection. The threshold of $200 \mathrm{~m}$ was chosen for the MLD so that AOU could be determined over a longer portion of the winter/spring period. For these cruises, AOU was calculated as follows. An oxygen anomaly was calculated assuming saturation at the observed sample temperature and salinity. The oxygen anomaly was integrated from 200-300 $\mathrm{m}$ and plotted as a function of day of the year. A Model I linear regression was applied to the data and the resulting slope and intercept were used to calculate the integrated AOU at the beginning of the shortened data record for each year and at 30 April (day of year 122). The difference between these two values was taken as the AOU associated with the material remineralized during the period of interest in this study. Oxygen data before 1993 were analyzed using a different detection system and therefore only data post-1993 are used in this analysis for consistency.

Statistical analyses were done using the routines in SigmaStat 3.5 (Systat Software Inc, San Jose, California). Data streams used for correlation analyses were averaged by month so that each pair of variables had the same number of measurements.

\section{Results}

\subsection{Particle production in the euphotic zone}

In addition to the seasonal pattern in Sargasso Sea biogeochemical processes (Steinberg et al., 2001), underlying multi-year trends in biological carbon pump parameters are apparent and statistically robust. The data presented in this manuscript are only from the winter/spring period each year and therefore no seasonal detrending of the data was performed. Over the 17-year data record presented here, euphotic zone $(0-140 \mathrm{~m})$ integrated stocks of total chlorophyll a (TChl- $a$ ), suspended particulate organic carbon (POC), rates of primary production and shallow $(150 \mathrm{~m})$ POC export all display significant (least squares Model 1 linear 
Table 1. Rates of change in biogeochemical parameters in the Sargasso Sea. Statistics provided for the entire period, as well as divided up into the two periods of interest as defined by the phase of the winter NAO index. $n / s=$ no significant change. Data in the "Period Change" column are given as the absolute change, in appropriate units, from the beginning of the time period as well as the percent change in parentheses.

\begin{tabular}{|c|c|c|c|c|c|c|}
\hline Parameter & Time period & Slope \& Std. Error & Period Change & p-value & $r^{2}$ & $n$ \\
\hline \multirow{4}{*}{ Int. TChl- $a\left(0-140 \mathrm{~m} ; \mathrm{mg} \mathrm{m}^{-2}\right)$} & 1990-1995 & $1.34 \pm 0.51$ & $+8.04(\sim 34 \%)$ & 0.01 & 0.11 & 50 \\
\hline & 1996-2007 & $1.71 \pm 0.47$ & $+18.7(\sim 62 \%)$ & $<0.01$ & 0.59 & 58 \\
\hline & 1990-2007 & $1.13 \pm 0.16$ & $+19.2(\sim 82 \%)$ & $<0.01$ & 0.33 & 108 \\
\hline & 1990-1995 & $0.20 \pm 0.33$ & $n / s$ & 0.56 & 0.01 & 58 \\
\hline \multirow[t]{2}{*}{ Int. Suspended POC (0-140 m; mmol C m $\left.{ }^{-2}\right)$} & 1996-2007 & $0.87 \pm 0.05$ & $+8.6(\sim 35 \%)$ & $<0.01$ & 0.60 & 51 \\
\hline & 1990-2007 & $0.64 \pm 0.10$ & $+10.9(\sim 44 \%)$ & $<0.01$ & 0.26 & 109 \\
\hline \multirow{4}{*}{ Int. Primary Production $\left(0-140 \mathrm{~m} ; \mathrm{mmol} \mathrm{C} \mathrm{m}^{-2} \mathrm{~d}^{-1}\right)$} & 1990-1995 & $0.01 \pm 0.06$ & $n / s$ & 0.79 & 0.01 & 53 \\
\hline & 1996-2007 & $2.95 \pm 0.76$ & $+32.5(\sim 98 \%)$ & $<0.01$ & 0.63 & 56 \\
\hline & 1990-2007 & $0.85 \pm 0.42$ & $+14.5(\sim 44 \%)$ & 0.04 & 0.04 & 109 \\
\hline & 1990-1995 & $0.01 \pm 0.12$ & $n / s$ & 0.97 & 0.01 & 36 \\
\hline \multirow{2}{*}{ POC flux @150m (mmolCm $\left.{ }^{-2} \mathrm{~d}^{-1}\right)$} & 1996-2007 & $0.18 \pm 0.08$ & $+1.95(\sim 66 \%)$ & 0.05 & 0.38 & 36 \\
\hline & 1990-2007 & $0.12 \pm 0.04$ & $+2.1(\sim 71 \%)$ & $<0.01$ & 0.12 & 72 \\
\hline \multirow{3}{*}{ POC flux @ $300 \mathrm{~m}\left(\mathrm{mmolCm} \mathrm{m}^{-2} \mathrm{~d}^{-1}\right)$} & 1990-1995 & $0.00 \pm 0.06$ & $n / s$ & 0.99 & 0.00 & 36 \\
\hline & 1996-2007 & $-0.03 \pm 0.06$ & $n / s$ & 0.62 & 0.01 & 36 \\
\hline & 1990-2007 & $0.02 \pm 0.02$ & $n / s$ & 0.47 & 0.01 & 72 \\
\hline
\end{tabular}

regression, $\mathrm{P}<0.05)$ increases in winter/spring values of $>44 \%$ (Fig. 1, Table 1). Increases in time however, were not uniform over the entire record. Indeed, TChl- $a$ was the only parameter of those four that showed a significant increase from 1990-1996, albeit with a lower slope than the later part of the record (Table 1). Moreover, the TChl- $a$ data for winters of 1995 and 1996 contribute disproportionately to the increase observed for the entire 1990-1996 period. All four parameters displayed increases with time from 19962007 with slopes that were much higher than for the 19901996 period or the entire dataset (Table 1).

Integrated TChl- $a$, primary production, and shallow POC export from 1996-2007, when the overall increase was greatest, were all significantly correlated with each other (Spearman Rank Order Correlation, all pairwise comparisons $\mathrm{P}<0.05, \mathrm{~N}=15$ or 17 depending upon comparison, Table 2), indicating a coherent euphotic zone response to a broader external forcing driven by increases in autotroph abundance. Corno et al. (2007), for the subtropical North Pacific, found that TChl- $a$ normalized primary production (i.e., the assimilation number) remained virtually constant suggesting the increase in primary production was due almost exclusively to the increase in biomass and not a change in physiological condition. Supporting the observed year-over-year increase in TChl- $a$, primary production and POC export was increasingly greater consumption of $\mathrm{NO}_{3}^{-}$and $\mathrm{PO}_{4}^{-3}$ (Fig. 2). The net $\mathrm{N}: \mathrm{P}$ drawdown ratio on these isopycnals ranged from 27 to $43 \mathrm{~mol}: \mathrm{mol}$, consistent with particulate bulk N:P ratios in this region (Ammerman et al., 2003) and N:P ratios of cyanobacteria (Bertilsson et al., 2003) that contribute substantially to total autotrophic carbon during the winter/spring (DuRand et al., 2001).
The increase in TChl- $a$ was not uniform across all taxonomic groups (Fig. 3, Table 3). Diatoms, an important mineral ballasted phytoplankton group, have been declining steadily with significant reductions (Mann-Whitney Rank Sum, $\mathrm{P}<0.05)$ in both absolute and relative abundance (Fig. 3a, Table 3). Absolute haptophyte biomass, a fraction of which is attributed to the coccolithophore Emiliania huxleyi in this region (Haidar and Thierstein, 2001), has not significantly changed over time (Mann-Whitney Rank Sum, $\mathrm{P}=0.55$; Fig. $3 \mathrm{~b}$, Table 3 ), but their relative contribution to TChl- $a$ has been reduced by approximately half due to increases in Synechococcus abundance over the past decade. Absolute pigment biomass of Synechococcus has increased by $\sim 45 \%$ over the past decade (Fig. 3c, Table 3 ) with an associated increase in relative abundance from $\sim 25 \%$ to $\sim 40 \%$ of TChl- $a$ (Fig. 3c, note the difference in scale between the two y-axes, Table 3). Euphotic zone integrated Synechococcus cell abundance, determined by analytical flow cytometry, has increased 3-fold since 2002 supporting the general trend in the HPLC data. Flow cytometric data on phycoerythrin and Chla fluorescence per cell for Synechococcus suggests a coincident decrease for both pigments over the record (Lomas, unpubl. data). Because the changes in pigment fluorescence are comparable for both pigments, the use of a fixed pigment ratio for the HPLC analysis remains valid, but it does create a disconnect between changes in cell numbers and pigment biomass estimates. A full explanation of these data is both premature and outside the scope of this manuscript. Using published estimates of cell carbon quotas and C:Chl- $a$ ratios for Synechococcus (Bertilsson et al., 2003), the increase in Synechococcus cell abundance accounts for $>50 \%$ of the TChl- $a$ increase. 
Table 2. Spearman Rank Correlation table of selected biogeochemical and environmental parameters. Within each cell, first row $=$ correlation coefficient and second row $=$ p-value. For each correlation, $\mathrm{N}=15$ to $17 . \delta \mathrm{NO}_{3}^{-}$and $\delta \mathrm{PO}_{4}^{-3}$ are $\mathrm{NO}_{3}^{-}$and $\mathrm{PO}_{4}^{-3}$ drawn down during the course of the winter/spring bloom; PProd = euphotic zone integrated primary production; $\delta \sigma_{T}=$ difference in $\sigma_{T}$ between $200 \mathrm{~m}$ and $5 \mathrm{~m}$ values. All other parameters as defined in the text. Only those correlations that are $\mathrm{P} \leq 0.1$ are shown. $\mathrm{P} \leq 0.1-$ normal font, $\mathrm{P} \leq 0.05-$ italics, $\mathrm{P} \leq 0.01$ - bold.

\begin{tabular}{|c|c|c|c|c|c|c|c|c|c|}
\hline & MLD & $\delta \mathrm{NO}_{3}^{-}$ & $\delta \mathrm{PO}_{4}^{-3}$ & $\mathrm{~T}_{\text {eff }}$ & PProd & TChl- $a$ & POC flux & MLD-CV & $\delta \sigma_{\theta}$ \\
\hline NAO & - & - & - & - & $\begin{array}{r}-0.48 \\
0.05\end{array}$ & $\begin{array}{l}-0.61 \\
<0.01\end{array}$ & $\begin{array}{r}-0.42 \\
0.08\end{array}$ & - & - \\
\hline MLD & & - & - & $\begin{array}{r}-0.39 \\
0.10\end{array}$ & - & - & - & - & - \\
\hline$\delta \mathrm{NO}_{3}^{-}$ & & & $\begin{array}{l}0.62 \\
0.01\end{array}$ & - & - & $\begin{array}{l}0.58 \\
0.03\end{array}$ & $\begin{array}{l}0.63 \\
0.01\end{array}$ & $\begin{array}{l}-0.67 \\
<0.01\end{array}$ & - \\
\hline$\delta \mathrm{PO}_{4}^{-3}$ & & & & $\begin{array}{r}-0.52 \\
0.03\end{array}$ & $\begin{array}{l}0.41 \\
0.10\end{array}$ & $\begin{array}{r}0.65 \\
<0.01\end{array}$ & - & - & $\begin{array}{r}-0.42 \\
0.10\end{array}$ \\
\hline$T_{\text {eff }}$ & & & & & $\begin{array}{r}-0.44 \\
0.08\end{array}$ & $\begin{array}{l}-0.61 \\
<0.01\end{array}$ & $\begin{array}{r}-0.46 \\
0.07\end{array}$ & - & - \\
\hline PProd & & & & & & $\begin{array}{l}0.51 \\
0.04\end{array}$ & $\begin{array}{l}0.60 \\
0.01\end{array}$ & $\begin{array}{r}-0.49 \\
0.05\end{array}$ & - \\
\hline TChl- $a$ & & & & & & & $\begin{array}{l}0.56 \\
0.02\end{array}$ & $\begin{array}{r}-0.48 \\
0.05\end{array}$ & - \\
\hline POC flux & & & & & & & & $\begin{array}{l}-0.65 \\
<0.01\end{array}$ & - \\
\hline MLD-CV & & & & & & & & & - \\
\hline
\end{tabular}

\subsection{Particle remineralization in the mesopelagic}

This shift in the relative abundance of specific phytoplankton groups after ca. 1996 appears to have altered the magnitude and biological lability of the exported particulate matter. The significant increase in shallow $(150 \mathrm{~m})$ POC export did not result in increased POC export to the deeper mesopelagic zone $(>300 \mathrm{~m})$. The $\sim 60 \%$ increase in POC export at $150 \mathrm{~m}$ has been countered by a significant decrease in mesopelagic transfer efficiency (defined as $T_{\text {eff }}$; Fig. $4 a$ ) such that POC fluxes at $300 \mathrm{~m}$ remained statistically identical over the entire time-series (Fig. 4b, Table 1). This observation is not confounded by changes in the relative depths of the traps (where particles are captured) and euphotic zone (where some particles are produced) as there has only been a $\sim 2 \mathrm{~m}$ shoaling of the $1 \%$ light depth over the past two decades $(86.6 \pm 10.4 \mathrm{~m}$ from 1992 to 1999 and $84.8 \pm 11.6 \mathrm{~m}$ from 2000 to 2007 ; Buesseler and Boyd, 2009). The coherence of increased primary production, POC flux at $150 \mathrm{~m}$ and attenuation of this flux ( $\left.T_{\text {eff }}\right)$ with depth suggests that ecosystem pathways in the mesopelagic respond on similar timescales and proportionately with euphotic zone pathways (Spearman Rank correlation, $\mathrm{P} \leq 0.07$ for all pairwise comparisons; Table 2).

The absolute magnitude of POC attenuation in the mesopelagic zone (150-300 m) was greater after ca. 1996 than in the prior decade (Student's t-test with unequal variance, $\mathrm{P}<0.01$; Fig. 4a). This increase in POC remineralization was associated with a significant (Student's t-test with unequal variance, $\mathrm{P}<0.01$; Fig. $4 \mathrm{~d}$ ) increase in apparent oxy- gen utilization (AOU; Fig. 4d) suggesting that POC attenuation may be due to increased mesopelagic metabolic activity (Steinberg et al., 2008b). The temporal patterns in $T_{\text {eff }}$ and AOU are different and could suggest other explanations. Substantial dissolution of particulate material post-collection in the trap tubes can occur, averaging $\sim 30 \%$ for carbon (reviewed by Antia, 2005). The reasonably monotonic trend of a phytoplankton community increasingly dominated by small prokaryotes might result in the dissolution of an increasingly large fraction of the trap POC. Therefore $T_{\text {eff }}$, as it was calculated from trap measurements, might reflect dissolution in the trap as much as metabolic consumption of POC. The observed step-change in AOU reflects complications in the calculation itself (see methods for details) as well as a more rapid change in system response. Reconciling the temporal response of these two estimates of mesopelagic carbon attenuation would require more focused process research, particularly on the response of bacteria versus metazoans with time.

Mesopelagic temperatures have been warming at $\sim 0.004^{\circ} \mathrm{C}^{-1}$, and while significant for stratification, this change is too small, even over a decade, to affect metabolic rates of individual organisms (which have a $Q_{10}$ of $\sim 2$ for many physiological processes; e.g., Eppley, 1972). Therefore the increase in metabolic activity is more likely associated with an increase in heterotrophic biomass or changes in its composition. Mesopelagic Bacterial Carbon Demand (BCD) has decreased significantly (least squares Model 1 linear regression, $\mathrm{P}<0.01$, Fig. 4d) from 1996 to 
Table 3. Rates of change in phytoplankton composition parameters in the Sargasso Sea. Statistics provided for the entire period, as well as divided up into the two periods of interest as defined by the phase of the winter NAO index. $n / s=$ no significant change. Data in the "Period Change" column are given as the absolute change in appropriate units and as percent increase from the beginning of the time period.

\begin{tabular}{|c|c|c|c|c|c|c|}
\hline Parameter & Time period & Slope \& Std. Error & Period Change $(\%)$ & $\mathrm{p}$-value & $r^{2}$ & $n$ \\
\hline \multirow{4}{*}{ Chla diatom $\left(\mathrm{mg} \mathrm{m}^{-2}\right)$} & 1990-1996 & $-0.03 \pm 0.01$ & $-0.15(\sim 74 \%)$ & 0.05 & 0.07 & 58 \\
\hline & 1996-2007 & $-0.03 \pm 0.01$ & $-0.24(\sim 110 \%)$ & 0.03 & 0.11 & 42 \\
\hline & 1990-2007 & $-0.02 \pm 0.00$ & $-0.34(\sim 113 \%)$ & $<0.01$ & 0.53 & 100 \\
\hline & 1990-1996 & $0.72 \pm 0.27$ & $+5.06(\sim 56 \%)$ & $<0.01$ & 0.12 & 58 \\
\hline \multirow{3}{*}{ Chla hapto $\left(\mathrm{mg} \mathrm{m}^{-2}\right)$} & 1996-2007 & $-0.28 \pm 0.12$ & $n / s$ & 0.05 & 0.09 & 42 \\
\hline & 1990-2007 & $-0.07 \pm 0.11$ & $n / s$ & 0.55 & 0.02 & 100 \\
\hline & 1990-1996 & $-0.03 \pm 0.08$ & $n / s$ & 0.70 & $<0.01$ & 58 \\
\hline \multirow{3}{*}{ Chlapro $\left(\mathrm{mg} \mathrm{m}^{-2}\right)$} & 1996-2007 & $0.07 \pm 0.09$ & $n / s$ & 0.43 & 0.02 & 42 \\
\hline & 1990-2007 & $0.06 \pm 0.05$ & $\mathrm{n} / \mathrm{s}$ & 0.25 & 0.08 & 100 \\
\hline & 1990-1996 & $4-0.10 \pm 0.15$ & $n / s$ & 0.50 & 0.07 & 58 \\
\hline \multirow{2}{*}{ Chlasyn $\left._{\text {Syg m}}{ }^{-2}\right)$} & 1996-2007 & $0.55 \pm 0.17$ & $+3.85(\sim 46 \%)$ & $<0.01$ & 0.30 & 42 \\
\hline & 1990-2007 & $0.34 \pm 0.10$ & $+5.78(\sim 64 \%)$ & $<0.01$ & 0.42 & 100 \\
\hline Int. Prochlorococcus $\left(\times 10^{11}{\text { cells } \mathrm{m}^{-2}}^{-2}\right.$ & 2002-2007 & $1.77 \pm 1.6$ & $n / s$ & 0.28 & 0.04 & 30 \\
\hline Int. Synechococcus $\left(\times 10^{11}\right.$ cells $\left.\mathrm{m}^{-2}\right)$ & 2002-2007 & $5.09 \pm 1.36$ & $+26.5(\sim 170 \%)$ & 0.01 & 0.33 & 30 \\
\hline
\end{tabular}
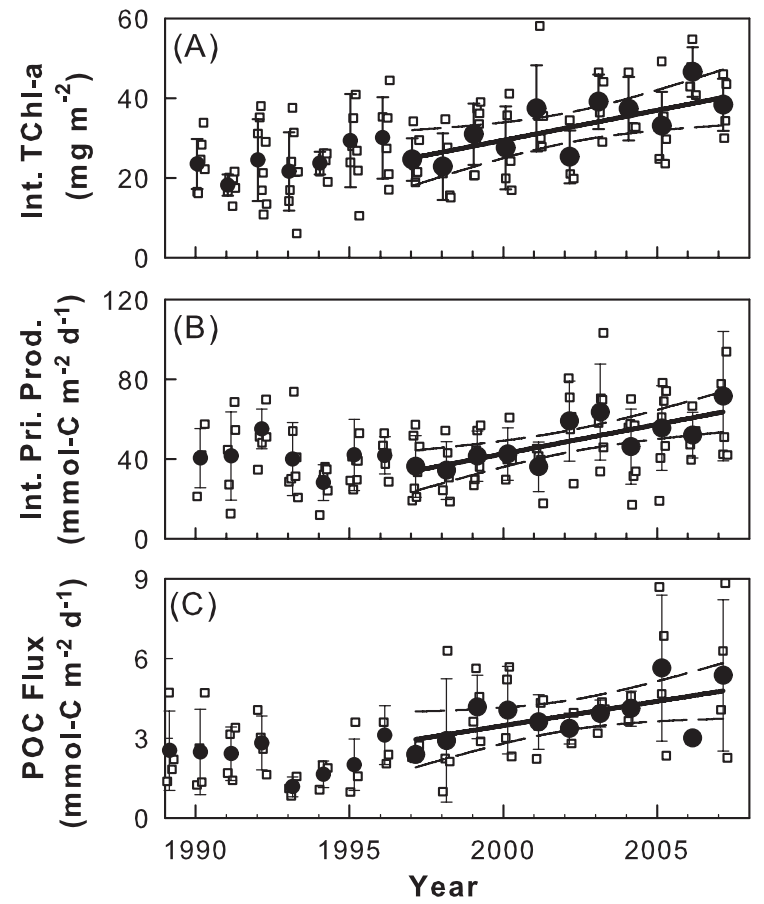

Fig. 1. Time-series, data from January to April each year, of biological carbon pump components in the Sargasso Sea. (a) Integrated $(0-140 \mathrm{~m})$ HPLC TChl- $a$, (b) integrated (0-14 m) in situ primary production and (c) sediment trap POC flux at $150 \mathrm{~m}$. In all panels, open squares are data for January through April of each year. The filled symbols are the mean ( \pm std. dev.) of the data for each winter/spring period. The solid lines in each panel are the least squares Model 1 linear regression and 95\% confidence intervals (dashed line). All linear regressions are significant, $\mathrm{P} \leq 0.05$.
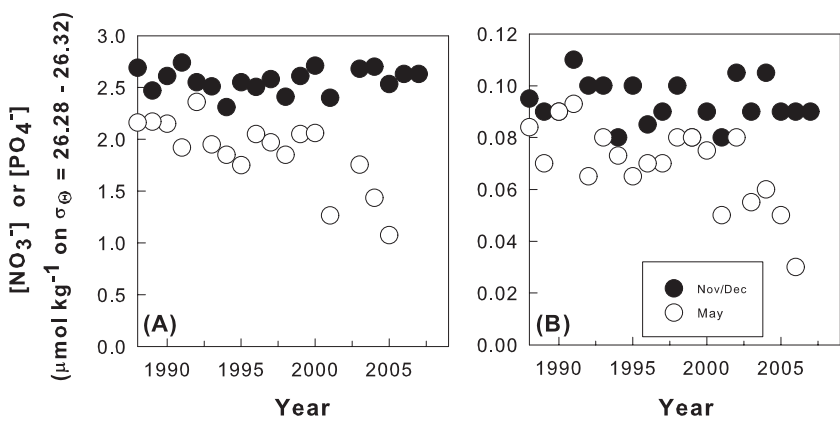

Fig. 2. Time-series plots of (a) $\left[\mathrm{NO}_{3}^{-}\right]$and (b) $\left[\mathrm{PO}_{4}^{-3}\right]$ concentrations before (Nov/Dec, filled circles) and after (May, open circles) the winter/spring period on isopycnal band $\sigma_{\theta}=26.28$ $26.32 \mathrm{~kg} \mathrm{~m}^{-3}$. Lines are drawn to the data to depict trends and are not statistical fits.

2007 due to decreases in bacterial abundance. Data prior to 1996 are too few to support extensive analysis. This decrease in free living BCD is substantial as estimates have decreased from roughly twice the POC attenuation to one-half these values. As a result, the fraction of AOU associated with biota other than free-living bacteria must have increased; most probably particle-attached bacteria (which our method doesn't account for) and zooplankton. At this time there is no data to directly evaluate the former, although it is hypothesized that attached bacterial activity would increase with increased POC flux. 

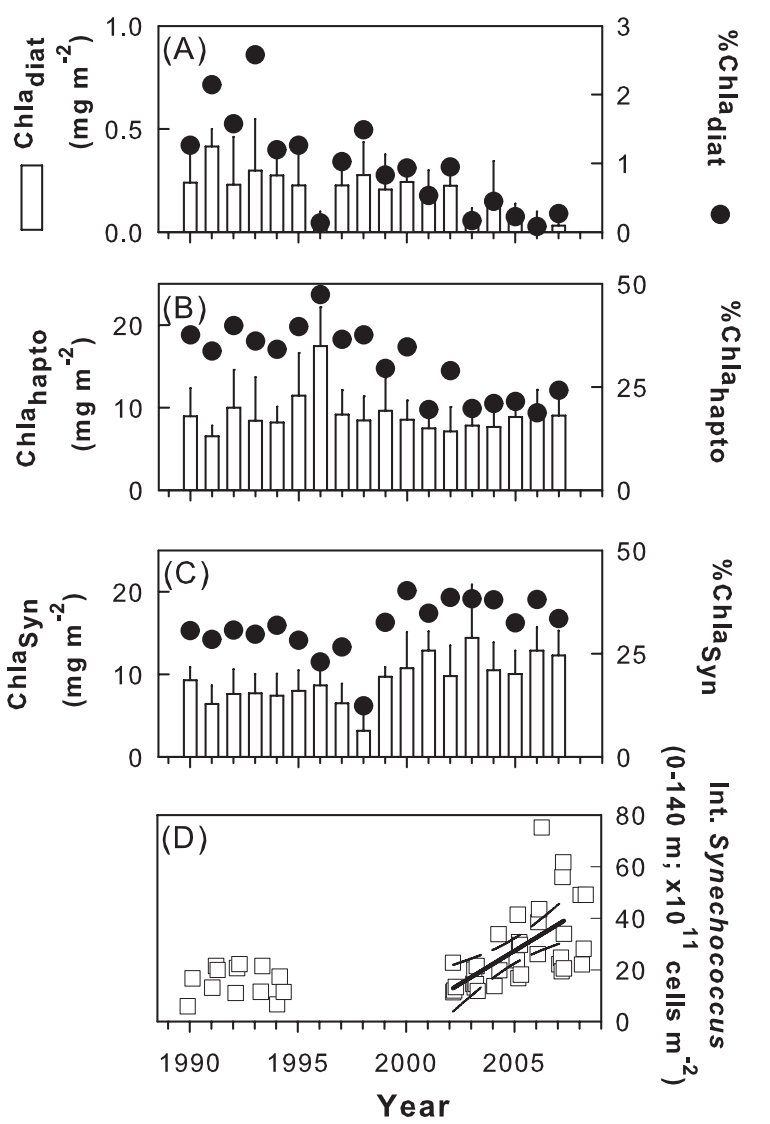

Fig. 3. Time-series of phytoplankton taxonomic groups determined from HPLC pigment analysis as described in the text. (a) diatoms, (b) haptophytes, and (c) Synechococcus. Phytoplankton group biomass estimates $\left(0-140 \mathrm{~m} ; \mathrm{mg} \mathrm{m}^{-2}\right.$; open bars) are given as the mean ( \pm std. dev.) for January to April of each year and their percent contribution to TChl- $a$ (filled circles). (d) Integrated Synechococcus abundances $\left(0-140 \mathrm{~m} ; \times 10^{11}\right.$ cells $\left.^{-2}\right)$ as determined by direct analytical flow cytometric counts. The solid line through data from 2002 to 2007 is the least squares Model 1 regression, significant at the $\mathrm{P}<0.01$ level, and predicted $95 \%$ confidence intervals (dashed lines). Data from 1991 to 1994 were taken from DuRand et al. (2001), as available on the CD that accompanied the Deep-Sea Res. Pt. II, 48(8/9) in which that data were originally published.

Total epipelagic mesozooplankton biomass in the Sargasso Sea (e.g., 200-500 $\mu \mathrm{m}$ size class), has increased approximately 2.5 fold since 1994 (Steinberg et al., 2008a; Fig. 5). Too few data are available prior to 1994 to determine if there was a different trend in zooplankton biomass in the early 1990's. As mesozooplankton metabolic rates and production generally scale with biomass (e.g., Roman et al., 2002), the increased mesozooplankton biomass would equate to increased metabolic demand and could contribute to the observed increase in AOU. From data presented in Roman et al. (2002), we calculate an average (19941997) total mesozooplankton respiration rate (and therefore approximate contribution to AOU) at BATS, integrated from $0-150 \mathrm{~m}$, of $\sim 2.2 \mathrm{mmol} \mathrm{C} \mathrm{m}^{-2} \mathrm{~d}^{-1}$, a value slightly larger than the $\triangle \mathrm{POC}$ observed during the same timespan (Fig. 4). We repeated the calculations outlined in Roman et al. (2002) for the longer dry weight biomass record (all size classes, Steinberg et al. 2008a) by converting to carbon biomass using Madin et al. (2001) and assuming a constant growth rate with time $\left(0.15 \mathrm{~d}^{-1}\right.$ determined by Roman et al. 2002). The increase in biomass would increase mesozooplankton respiration rates to $\sim 5.5 \mathrm{mmol} \mathrm{C} \mathrm{m}^{-2} \mathrm{~d}^{-1}$ by the end of the time-series; this change in respiration over time, $\sim 3.3 \mathrm{mmol} \mathrm{C} \mathrm{m}^{-2} \mathrm{~d}^{-1}$, is similar to the change in AOU before and after $\sim 1996-4.1 \mathrm{mmol} \mathrm{Cm}^{-2} \mathrm{~d}^{-1}$. Based on this back-of-the-envelope calculation, it appears that the change in zooplankton biomass and resultant respiration may account for a substantial fraction of the increase in AOU. It is important to note however, that some of the attenuation of POC flux may also be due to fragmentation of large aggregates into smaller particles with slower sinking rates by biological processes such as particle-attached microbial activity, zooplankton feeding, or zooplankton-induced shear (Steinberg et al., 2008b).

\section{Discussion}

This analysis of the Sargasso Sea biological carbon pump over the past two decades suggests that this ecosystem is not static as perhaps previously thought. The decision to separate the nearly two-decade dataset between 1995 and 1996 was not arbitrary. The primary reason is the well documented change in the phase of the NAO in the mid 1990's. Prior to the winter of 1996 the wintertime NAO was consistently positive and after 1996 was variable but on average neutral (discussed later). Given the generally well established linkages between modes of climate forcing and marine planktonic processes (e.g., Chavez et al., 2003; Corno et al., 2007; Karl et al., 2002) and in particular the NAO in the North Atlantic (Irigoien et al., 2000; Oschlies, 2001), a change in planktonic response was hypothesized to occur coincident with the change in the NAO. If the transition timing is moved three years on either side of 1996 (e.g., 1990-1993 and 19942007 or 1990-1999 and 2000-2007), non-significant trends remain non-significant and significant trends remain significant (data not shown). This suggests that the correlations observed and discussed below are robust and not dependent on the exact date chosen. Furthermore, a transition set at 1996 also explains the most variance in both time periods (i.e., extending the 1990-1996 period forward in time to include more data only reduces the $r^{2}$ value, and extending the 1996-2007 period back in time to include more data also decreases the $r^{2}$ value). Regardless of the choice of transition time point, there have been increases in biological carbon pump parameters over time that have coincided with a decrease in wintertime NAO over the same timeframe. 


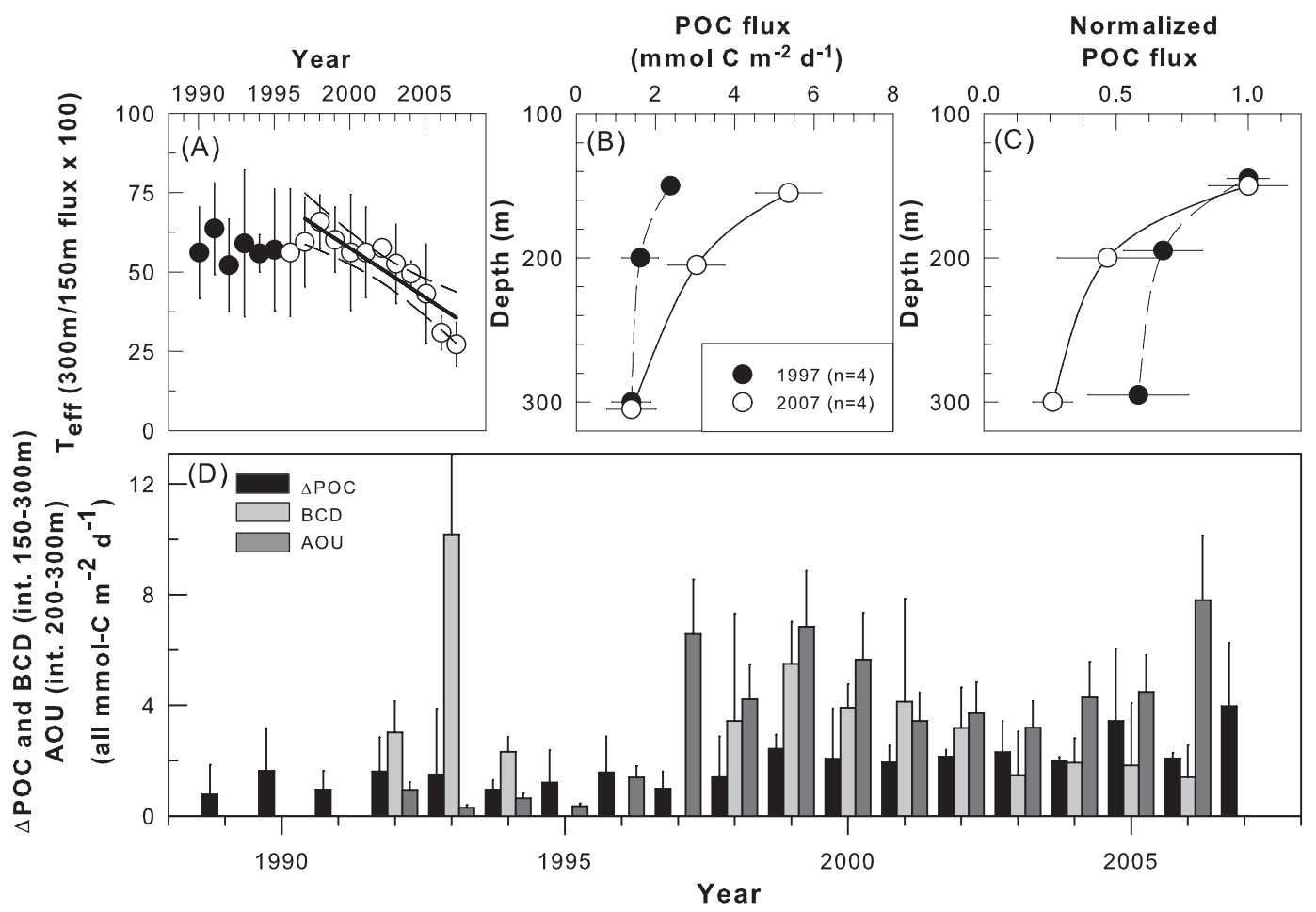

Fig. 4. Remineralization of sinking particulate organic carbon in the Sargasso Sea. (a) time-series of mean ( \pm std. dev.) winter/spring (January to April) mesopelagic transfer efficiency ( $\left.T_{\text {eff }}\right)$. Filled circles denote data from 1990 to 1996, and open circles denote the 1996 to 2007 period. (b) absolute POC flux profiles for January to April of 1997 (filled circles) and 2007 (open circles) are plotted as an example of the change in attenuation during this period. (c) POC flux profiles normalized to $150 \mathrm{~m}$ fluxes for January to April of 1997 (filled circles) and 2007 (open circles). (d) Time-series of sinking particulate organic carbon loss between 150 and $300 \mathrm{~m}$ ( $\Delta$ POC; black bars), 150 to $300 \mathrm{~m}$ integrated bacterial carbon demand (light grey bars), and 200 to $300 \mathrm{~m}$ apparent oxygen utilization (dark grey bars).

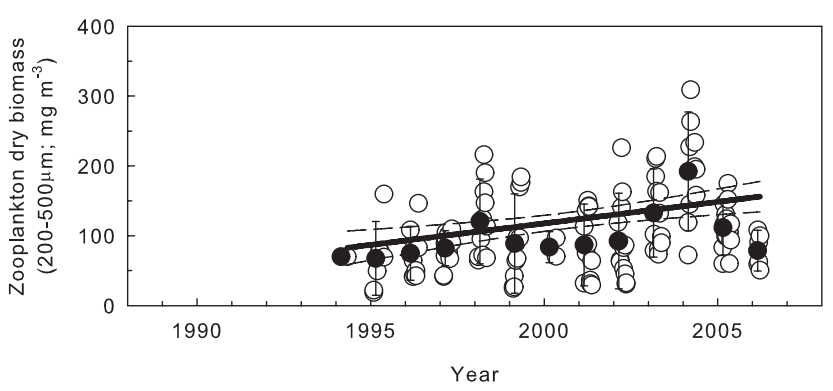

Fig. 5. Time-series of daytime zooplankton biomass (mg dry weight $\mathrm{m}^{-3}$ ) in the $200-500 \mu \mathrm{m}$ size class at the BATS site. Solid line is the least squares Model 1 regression, and the dashed lines are the $95 \%$ confidence intervals.

\subsection{Relationships between climate forcing and the Sargasso Sea biological carbon pump}

Additional physical and biogeochemical data allow an assessment of possible triggers for the changing strength and efficiency of the biological carbon pump. The most obvious are changes in upper ocean stratification and nutrient inputs, given that primary production in the subtropical North At- lantic is limited by the nutrient supply rate (Maranon, 2005), and how these may change in response to multi-year climate oscillations. No significant changes in wintertime stratification were apparent between the near surface and $200 \mathrm{~m}$ (Fig. 6a) in contrast to changes in summer time stratification which were large enough to drive an annual increase in stratification from 1989 to 2003 (Krause et al., 2009). Estimated MLDs consistently reached depths of 150 to $200 \mathrm{~m}$, with occasional mixing to $250 \mathrm{~m}$ (Fig. 6c); the depth of the 26.28 to $26.32 \mathrm{~kg} \mathrm{~m}^{-3}$ isopycnals from which we observed increased nutrient drawdown during the course of the winter/spring bloom (Fig. 2). Despite the similarity in estimated MLDs and apparent upper ocean stratification, it is hypothesized that there have been changes in physical forcing between the two decades of the BATS dataset. The wintertime (December through March) North Atlantic Oscillation (NAO) index, the dominant climate mode in this region (Marshall et al., 2001), shifted from consistently positive to more neutral values starting with the winter of 1996 (Fig. 6b); negative NAO values result in intensified midlatitude westerlies (Marshall et al., 2001). While the depth of mixing has not changed, the frequency of mixing in this region may have increased, suggested by the reduction in month-to-month variability of 


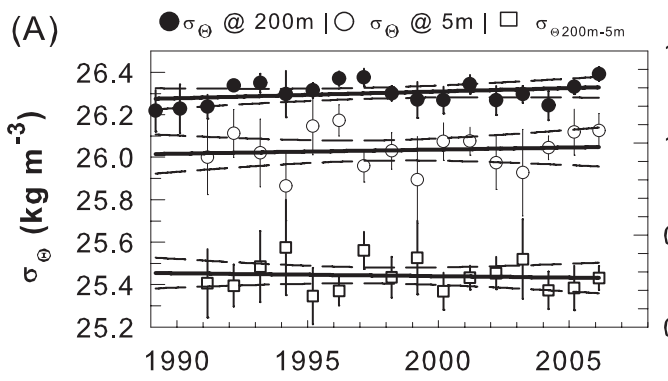

(C)
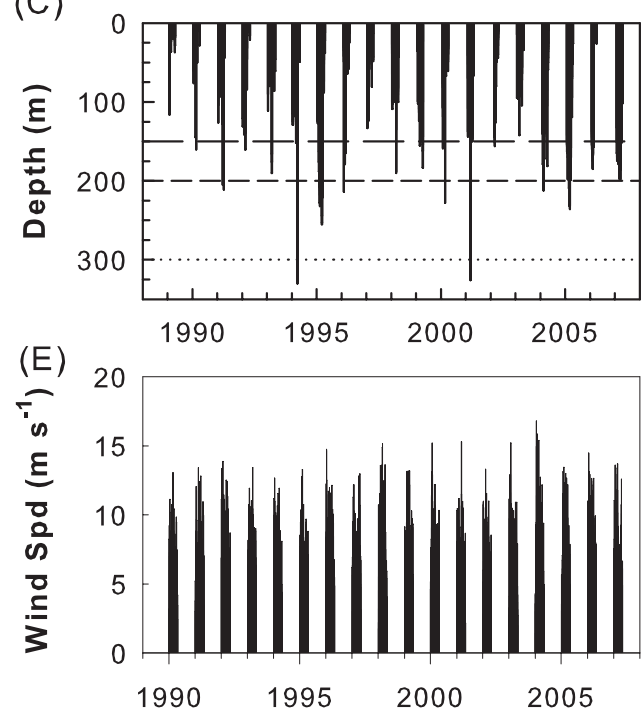

(B)

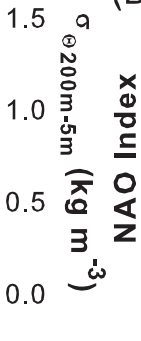

(D)
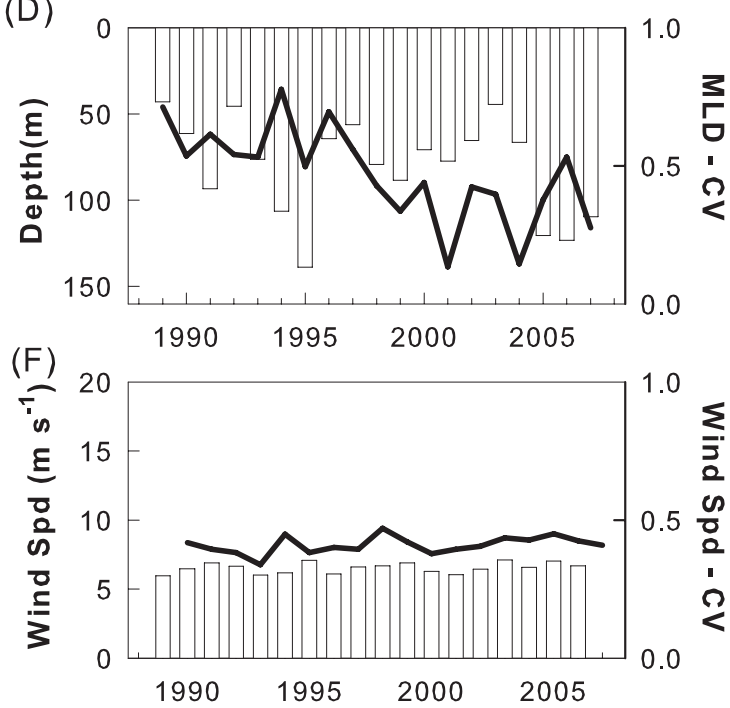

Fig. 6. Time-series of upper ocean physical forcing at BATS. (a) Mean ( \pm std. dev.) $\sigma_{\theta}\left(\mathrm{kg} \mathrm{m}^{-3}\right)$ for near surface water ( $5 \mathrm{~m}$; open circles) and $200 \mathrm{~m}$ (filled circles), and the difference between the two (open squares). Solid lines are the least square Model 1 linear regression and dashed lines are the 95\% confidence intervals. (b) winter (December through March) index of the NAO. (c) Estimated mixed layer depths using a variable $\sigma_{T}$ difference criterion of $0.02 \mathrm{~kg} \mathrm{~m}^{-3}$ difference from the surface $(\sim 5 \mathrm{~m})$ value. Horizontal lines denote the depths of the BATS sediment traps at 150, 200 and $300 \mathrm{~m}$. (d) Mean mixed layer depth (bars) and the coefficient of variation within each winter (solid line). (e) daily winter/spring wind speeds recorded at the Bermuda Airport. (e) Same as (c) but for wind speed.

estimated MLD (based upon calculated CV of $n=4$ monthly average MLDs) taken from cruise data during the duration of the winter/spring period (Fig. 7d). It is hypothesized that the change in the phase of the NAO has resulted in more continuous, but not necessarily deeper, mixing that enhances the supply of nutrients to the euphotic zone leading to more efficient and greater biological nutrient utilization (Fig. 2) and ultimately biomass accumulation (Fig. 1a). In support of this there are coherent statistical correlations between the NAO index and all euphotic zone carbon pump parameters (PP, TChl- $a$, POC flux; all $\mathrm{P} \leq 0.08$; Table 2), the strongest of which is a negative correlation (Spearman's Correlation, $r=-0.48, \mathrm{P}<0.02$ ) between euphotic zone integrated primary production and the wintertime NAO index (Fig. 7). This observation is consistent with previous findings based upon the BATS dataset (Bates, 2001; Lomas and Bates, 2004). In addition, the MLD coefficient of variation is negatively correlated with the biological carbon pump parameters (PP, TChl- $a$, POC flux; all $\mathrm{P} \leq 0.05$; Table 2). These findings suggest a mechanism by which shifts in a dominant climate mode for the North Atlantic may lead to increased productivity. It is important to point out that interactions between climate modes and mesoscale variability and the impact on vertical mixing at BATS is not understood, and it is possible that the presence of different mesoscale eddy features during the winter/spring period will modify the "convective mixing" signal (Mourino-Carballido, 2009).

In addition to mesoscale interactions, there are non-local impacts of changes in the NAO as well. For example, Palter et al. (2005) suggest that the phase of the NAO controls the nutrient reservoir in the North Atlantic subtropical mode water in a counterintuitive manner. They suggest that an NAO negative phase during mode water formation results in lower nutrient concentrations within the mode water which may reduce downstream primary production dependent upon convective mixing of nutrients from the mode water (i.e., at the BATS site). In contrast, formation of mode water during NAO positive phases results in higher nutrient concentrations and possibly higher downstream primary production. Nutrient concentrations shallower than the core of the mode water 


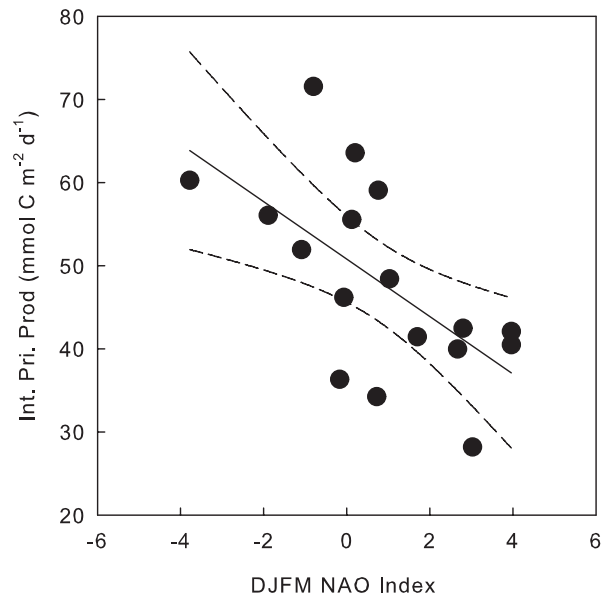

Fig. 7. Bivariate plot of euphotic zone integrated primary production $\left(\mathrm{mmol} \mathrm{C} \mathrm{m}^{-2} \mathrm{~d}^{-1}\right)$ vs. winter NAO index. Solid line is the least squares Model II regression and the dashed lines are the are $95 \%$ confidence intervals. Correlation is significant at the $\mathrm{P}<0.02$ level.

(mode water core is at $\sigma_{\theta} \sim 26.4 \mathrm{~kg} \mathrm{~m}^{-3}$ ), but still within the mode water do not show any significant trend with time (filled symbols Fig. 2). Perhaps this is due to the discrepancy in depths between the mode water core and MLD, or that perhaps the shift in the NAO is not strong or constant enough to impart the effect hypothesized by Palter et al. Thus, this non-local phenomenon seems to be of minor importance in explaining the observed patterns.

If our hypothesis is correct, that negative anomalies in the NAO result in more continuous mixing of the upper ocean supporting the increase in primary production and biomass accumulation, then why are diatoms declining (alternatively, why is Synechococcus increasing)? There are several possible explanations. First, in the Sargasso Sea, silica uptake by diatoms may be chronically substrate limited (Brzezinski and Nelson, 1996) thereby restricting their ability to respond to enhanced mixing and nutrient inputs. Silicate gradients are lower in the upper $250 \mathrm{~m}$ of the Sargasso Sea than $\mathrm{NO}_{3}^{-}$gradients such that mixing to depth will entrain relatively more $\mathrm{NO}_{3}^{-}$, thus exacerbating potential silica limitation. In contrast, Synechococcus populations in the Sargasso Sea have been shown to respond to nanomolar level $\mathrm{NO}_{3}^{-}$pulses by increasing net growth rates and most importantly for this discussion, accumulating biomass (Glover et al., 2007). Mourino-Carballido (2009) have also shown than Synechococcus is relatively more abundant in regions of cyclone/anticyclone interaction, where vertical nutrient pumping might be intensified. Second, salinity normalized DIC concentrations in the Sargasso Sea have been increasing at $0.80 \pm 0.06 \mu$ moles $\mathrm{kg}^{-1} \mathrm{yr}^{-1}$ with a consequent acidification of the surface ocean (Bates, 2007). Recent $\mathrm{CO}_{2}$ manipulation studies in other ocean regions show that under elevated $\mathrm{pCO}_{2}$ conditions diatoms are out competed by pico- and nano-phytoplankton when macronutrients are depleted (Hare et al., 2007) but that diatoms out compete pico- and nano-phytoplankton when nutrients are replete (Riebesell et al., 2007). While, both diatoms and Synechococcus both have enhanced growth rates under elevated $p \mathrm{CO}_{2}(\mathrm{Fu}$ et al., 2007; Riebesell et al., 1993) macronutrient limitation likely offsets these gains in diatoms, thus allowing Synechococcus to gain a competitive growth advantage. Lastly, common vertical migrators in the Sargasso Sea show a strong preference for grazing on diatoms relative to other co-occurring phytoplankton (Schnetzer and Steinberg, 2002b). Given the increase in daytime mesozooplankton biomass (Fig. 5), it is probable that grazing pressure on diatoms will also have increased from 1996-2007 potentially contributing to the decline in diatom abundance. A fraction of the mesozooplankton biomass increase is due to diel vertical migrators that are resident in the mesopelagic zone during the day (Madin et al., 2001; Steinberg et al., 2000), but active and passive POC fluxes attributed to vertically migrating mesozooplankton range from 3-18\% (Schnetzer and Steinberg, 2002a) with a long-term average closer to $6 \%$ (Lomas et al., 2002). While they may be important in diatom population dynamics, their contribution to export flux appears insufficient to account for the observed $60 \%$ increase POC flux. Consequently a mechanistic understanding of the role of vertically migrating mesozooplankton is incomplete at this time.

In contrast to some model predictions (Bopp et al., 2005; Laws et al., 2000), data presented here for the Sargasso Sea shows that shallow POC export increases with a shift to smaller phytoplankton. This observation, in conjunction with the discussion of zooplankton in the previous paragraph, suggests that particle aggregation in relatively low biomass environments may be an underappreciated process in the "packaging" of particles as they leave the euphotic zone in the oligotrophic North Atlantic (Jackson et al., 2005). Indeed, these ideas are at the heart of two competing ideas linking phytoplankton community composition and POC export. It is a long-held belief that regions of efficient and high absolute POC export rates are dominated by diatoms and coccolithophores and that these groups contribute disproportionately to these high fluxes. This is in part due to the mineral tests encasing these groups that act to increase settling rate, and therefore decrease contact time in the biological active upper ocean (Armstrong et al., 2002). As a result model predictions of the future strength of the biological carbon pump appear to be inextricably linked to changes in the abundance of diatoms. Interestingly, Emerson et al. (2001) suggest that per unit area oligotrophic systems, which are dominated by the biomass of small cells not diatoms, can have annual POC export rates similar to subpolar regions. This supports the recent hypothesis that all phytoplankton contribute to carbon export rates out of the euphotic zone in proportion to primary production, although specific export mechanisms may differ (Richardson and Jackson, 2007). If aggregation were a significant process in the Sargasso Sea biological carbon 
pump, it could explain both the increase in POC flux with smaller phytoplankton and enhanced remineralization within the upper mesopelagic zone. Unfortunately data on aggregate abundance, or other descriptive characterizations of flux material, are not available at this time for the Sargasso Sea that would allow a more complete evaluation of this hypothesis.

\section{Global implications}

The findings presented here suggest there may be long timescale, climate-related shifts in phytoplankton community composition in the subtropical North Atlantic that have significant, and perhaps unanticipated, implications for the production and export of POC in this oligotrophic gyre. A similar climate-related shift in phytoplankton community composition and increase in TChl- $a$ and primary production has been observed in the North Pacific (Karl et al., 2001), suggesting the possibility of observed biological responses to climate forcing in the broader subtropical oceans. However, there is a difference in that stratification was not shown to increase in the Sargasso Sea as it did in the North Pacific along with the increase in primary production, and therefore the exact physical mechanism may differ between the two oligotrophic gyres. The data presented here suggests that in the oligotrophic North Atlantic there is a tight coupling between enhanced biological production and carbon export from the euphotic zone and its attenuation in the mesopelagic such that they increase in concert following a shift in the wintertime NAO index that enhances vertical mixing.

Regional variability of $T_{\text {eff }}$ within the mesopelagic is not well constrained (Buesseler et al., 2007), and in no model that we are aware of does $T_{\text {eff }}$ change temporally with euphotic and mesopelagic zone processes. If the data at the HOT (Karl et al., 2001) and BATS are representative of the broader oligotrophic gyres, and assuming they contribute $\sim 60 \%$ of the global shallow export production of $11 \mathrm{Pg} \mathrm{Cyr}^{-1}$ (Laws et al., 2000), not accounting for the decrease in $T_{\text {eff }}$ would result in an overestimation of POC sequestration below $300 \mathrm{~m}$ of $2.3 \mathrm{Pg} \mathrm{Cyr}^{-1}$. For reference, global anthropogenic $\mathrm{CO}_{2}$ emissions are 6$7 \mathrm{Pg} \mathrm{C} \mathrm{yr}^{-1}$. While the uncertainties on this calculation are quite large, it highlights that not accounting for tight coupling between metabolic activities in the euphotic and mesopelagic zones, or assuming that the oligotrophic gyre biological carbon pumps are static, can have a substantial impact of our understanding of the oceans role in carbon sequestration.
Acknowledgements. The authors thank the captains and crews of the R/Vs Weatherbird II and Atlantic Explorer as well as the BATS technicians and scientists, past and present, whose diligence and dedication has resulted in the generation of the dataset presented in this manuscript. Specifically we thank Debra Lomas who assisted with the data analysis. We thank the National Science Foundation Chemical and Biological Oceanography Programs for continued support of the BATS program through the following awards: OCE 88-01089, OCE 93-01950, OCE 9617795, OCE 0326885, and OCE 0752366. This is BIOS contribution No. 1720.

Edited by: E. Marañón

\section{References}

Ammerman, J. W., Hood, R. R., Case, D. and Cotner, J. B.: Phosphorus deficiency in the Atlantic: an emerging paradigm in oceanography, EOS, 84, 165-170, 2003.

Anderson, R., Bidigare, R., Keller, M., and Latasa, M.: A comparison of HPLC pigment signatures and electron microscopic observatins for oligotrophic waters of the North Atlantic and Pacific Oceans, Deep-Sea Res. Pt. II, 43, 517-537, 1996.

Antia, A. N.: Particle-associated dissolved elemental fluxes: revising the stochiometry of mixed layer export, Biogeosciences Discuss., 2, 275-302, 2005,

http://www.biogeosciences-discuss.net/2/275/2005/.

Armstrong, R., Lee, C., Hedges, J., Honjo, S., and Wakeham, S.: A new mechanistic model for organic carbon fluxes in the ocean based on the quantitative association of POC with ballast minerals, Deep-Sea Res. Pt. II, 49, 219-236, 2002.

Bates, N.: Interannual variability of the oceanic $\mathrm{CO}_{2}$ sink in the subtropical gyre of the North Atlantic Ocean over the last two decades, J. Geophys. Res., 112, C09013, doi:09010.01029/02006JC003759, 2007.

Bates, N. R.: Interannual variability of oceanic $\mathrm{CO}_{2}$ and biogeochemical properties in the Western North Atlantic subtropical gyre, Deep-Sea Res. Pt. II, 48, 1507-1528, 2001.

Behrenfeld, M., O’Malley, R., Siegel, D., McClain, C., Sarmiento, J., Feldman, G., Milligan, A. J., Falkowski, P., Letelier, R. M., and Boss, E.: Climate-driven trends in contempary ocean productivity, Nature, 444, 752-755, 2006.

Bertilsson, S., Berglund, O., Karl, D. M., and Chisholm, S. W.: Elemental composition of marine Prochlorococcus and Synechococcus: implications for the ecological stoichiometry of the sea., Limnol. Oceanogr., 48, 1721-1731, 2003.

Bidigare, R.: Analysis of algal chlorophylls and carotenoids, in: Marine Particles: Analysis and Characterization, edited by: Hurd, D. and Spencer, D., American Geophysical Union, Washington DC, 119-123, 1991.

Bopp, L., Aumont, O., Cadule, P., Alvain, S., and Gehlen, M.: Response of diatoms distribution to global warming and potential implications: A global model study, Geophys. Res. Lett., 32, L19606, doi:19610.11029/12005GL023653, 2005.

Brzezinski, M. A. and Nelson, D. M.: Chronic substrate limitation of silicic acid uptake rates in the western Sargasso Sea, Deep-Sea Res., 43, 437-453, 1996.

Buesseler, K. O. and Boyd, P. W.: Shedding light on processes that control particle export and flux attenuation in the twilight zone 
of the open ocean, Limnol. Oceanogr., 54, 1210-1232, 2009.

Buesseler, K. O., Lamborg, C., Boyd, P., Lam, P., Trull, T., Bidigare, R., Bishop, J. K. B., Casciotti, K. L., Dehairs, F., Elskens, M., Honda, M., Karl, D. A., Siegel, D., Silver, M., Steinberg, D. K., Valdes, J. R., Van Mooy, B. A. S., and Wilson, S.: Revisiting carbon flux through the ocean's twilight zone, Science, 316, 567-570, 2007.

Carlson, C. A. and Ducklow, H. W.: Growth of bacterioplankton and consumption of dissolved organic carbon in the Sargasso sea, Aquat. Microb. Ecol., 10, 69-85, 1996.

Carlson, C. A., Ducklow, H. W., and Sleeter, T. D.: Stocks and dynamics of bacterioplankton in the northwestern Sargasso Sea, Deep-Sea Res. Pt. I, 43, 491-515, 1996.

Chavez, F., Ryan, J. P., Lluch-Cota, S., and Niquen, M.: From anchovies to sardines and back: Multidecadal change in the Pacific Ocean, Science, 299, 217-221, 2003.

Corno, G., Karl, D., Church, M., Letelier, R., Lukas, R., Bidigare, R., and Abbott, M.: Impact of climate forcing on ecosystem processes in the North Pacific Subtropical Gyre, J. Geophys. Res. Oceans, 112, C04021, 04010.01029/02006JC003730, 2007.

Dickey, T., Zedler, S., Yu, X., Doney, S. C., Frye, D., Jannasch, H., Manov, D., Sigurdson, D., McNeil, J. D., Dobeck, L., Gilboy, T., Bravo, C., Siegel, D. A., and Nelson, N.: Physical and biogeochemical variability from hours to years at the Bermuda Testbed Mooring site: June 1994-March 1998, Deep-Sea Res. Pt. II, 48, 2105-2140, 2001.

Dore, J., Houlihan, T., Hebel, D., Tien, G., Tupas, L., and Karl, D.: Freezing as a method of sample preservation for the analysis of dissolved inorganic nutrients in seawater, Mar. Chem., 53, 173185,1996

DuRand, M. and Olson, R.: Contributions of phytopankton light scattering and cell concentration changes to diel variations in beam attenuation in the equatorial Pacific from flow-cytometric measurements of pico-, ultra-, and nanoplankton., Deep-Sea Res. Pt. II, 43, 891-906, 1996.

DuRand, M., Olson, R., and Chisholm, S.: Phytoplankton population dynamics at the Bermuda Atlantic Time- series station in the Sargasso Sea, Deep-Sea Res. Pt. II, 48, 1983-2003, 2001.

Emerson, S. R., Mecking, S., and Abell, J.: The biological pump in the subtropical North Pacific Ocean: Nutrient sources, Redfield ratios and recent changes, Glob. Biogeochem. Cy., 15, 535-554, 2001.

Eppley, R. W.: Temperature and phytoplankton growth in the sea, Fish. B., 70, 1063-1085, 1972.

Field, C. B., Behrenfeld, M. J., Randerson, J. T., and Falkowski, P. G.: Primary production of the biosphere: Integrating the terrestrial and oceanic components, Science, 281, 237-240, 1998.

Fu, F., Warner, M. E., Zhang, Y., Feng, Y., and Hutchins, D. A.: Effects of increased temperature and $\mathrm{CO}_{2}$ on photosynthesis, growth, and elemental ratios in marine Synechococcus and Prochlorococcus (Cyanobacteria), J. Phycol., 43, 485-496, 2007.

Glover, H. E., Garside, C., and Trees, C.: Physiological responses of Sargasso Sea picoplankton to nanomolar nitrate perturbations, J. Plankton Res., 29, 263-274, 2007.

Gruber, N. and Sarmiento, J. L.: in: The Sea: Biological-Physical Interactions in the Oceans, edited by: Robinson, A. R., McCarthy, J. J., and Rothschild, B. J., Wiley, New York, 337-399, 2002.
Haidar, A. and Thierstein, H.: Coccolithophore dynamics off Bermuda (N. Atlantic), Deep-Sea Res. Pt. II, 48, 1897-1924, 2001.

Hare, C. E., Leblanc, K., DiTullio, G. R., Kudela, R. M., Zhang, Y., Lee, P. A., Riseman, S., and Hutchins, D. A.: Consequences of increased temperature and $\mathrm{CO}_{2}$ for phytoplankton community structure in the Bering Sea., Mar. Ecol-Prog. Ser., 352, 9-16, 2007.

Irigoien, X., Harris, R., Head, R., and Harbour, D.: North Atlantic Oscillation and spring bloom phytoplankton composition in the English Channel, J. Plankton Res., 22, 2367-2371, 2000.

Jackson, G. A., Waite, A. M., and Boyd, P. W.: Role of algal aggregation in vertical carbon export during SOIREE and in other low biomass environments, Geophys, Res, Lett., 32, L13607, doi:13610.11029/12005GL023180, 2005.

Karl, D., Bidigare, R., and Letelier, R.: Long-term changes in plankton community structure and productivity in the North $\mathrm{Pa}-$ cific Subtropical Gyre: the domain shift hypothesis, Deep-Sea Res. Pt. II, 48, 1449-1470, 2001.

Karl, D., Bidigare, R., and Letelier, R. M.: Sustained and aperiodic variability in organic matter production and phototrophic microbial community structure in the North Pacific Subtropical Gyre, in: Phytopankton Productivity and Carbon Assimilation in Marine and Freshwater Ecosystems, edited by: Le B Williams, P. J., Thomas, D., and Reynolds, C. S., Blackwell, Malden, Massachusetts, 2002.

Knap, A., Michaels, A., Steinberg, D., Bahr, F., Bates, N., Bell, S., Countway, P., Close, A., Doyle, A., Howse, F., Gundersen, K., Johnson, R., Little, R., Orcutt, K., Parsons, R., Rathbun, C., Sanderson, M., Stone, S., BATS Methods Manual Version 4, U.S. JGOFS Planning Office, Woods Hole, 1997.

Knauer, G., Martin, J., and Bruland, K.: Fluxes of particulate carbon, nitrogen, and phosphorus in the upper water column of the northeast Pacific, Deep-Sea Res., 26, 97-108, 1979.

Krause, J., Lomas, M., and Nelson, D.: Biogenic silica at the Bermuda Atlantic Time-series Study site in the Sargasso Sea: Temporal changes and their inferred controls based on a 15-year record, Glob. Biogeochem. Cy., 23, GB3004, doi:3010.1029/2008GB003236, 2009.

Laws, E., Falkowski, P., Smith, W. J., Ducklow, H., and McCarthy, J.: Temperature effects on export production in the open ocean, Glob. Biogeochem. Cy., 14, 1232-1246, 2000.

Letelier, R., Bidigare, R., Hebel, D., Ondrusek, M. E., Winn, C., and Karl, D. M.: Temporal variability of phytoplankton community structure based on pigment analysis, Limnol. Oceanogr., 38, 1420-1437, 1993.

Lomas, M., Bates, N., Knap, A., Karl, D., Lukas, R., Landry, M., Bidigare, R., Steinberg, D., and Carlson, C.: Refining our understanding of ocean biogeochemistry and ecosystem functioning, EOS, 83, 559-561, 2002.

Lomas, M. W. and Bates, N. R.: Potential controls on interannual partitioning of organic carbon during the winter/spring phytoplankton bloom at the Bermuda Atlantic Time-series Study (BATS) site, Deep-Sea Res. Pt. I, 51, 1619-1636, 2004.

Madin, L. P., Horgan, E. F., and Steinberg, D. K.: Zooplankton at the Bermuda Atlantic Time-series Study (BATS) station: diel, seasonal and interannual variation in biomass, 1994-1998, DeepSea Res. Pt. II, 48, 2063-2082, 2001.

Maranon, E.: Phytoplankton growth rates in the Atlantic subtropical 
gyres, Limnol. Oceanogr., 50, 299-310, 2005.

Maranon, E., Behrenfeld, M., Gonzalez, N., Mourino, B., and Zubkov, M.: High variability of primary production in the oligotrophic waters of the Atlantic Ocean: uncoupling from phytoplankton biomass and size structure, Mar. Ecol.-Prog. Ser., 257, 1-11, 2003.

Marshall, J., Kushnir, Y., Battisti, D., Chang, P., Czaja, A., Dickson, A. G., Hurrell, J., McCartney, M. S., Saravan, R., and Visbeck, M.: North Atlantic climate variability: Phenomena, impacts and mechanisms., Int. J. Climatol., 21, 1863-1898, 2001.

Michaels, A. F. and Silver, M. W.: Primary production,sinking fluxes, and the microbial food web, Deep-Sea Res., 35, 473-490, 1988.

Mourino-Carballido, B.: Eddy driven pulses of respiration in the ocean, Deep Sea Res. Pt. I, 56, 1242-1250, 2009.

Neuer, S., Davenport, B., Freudenthal, T., Wefer, G., Llinás, O., Rueda, M., Steinberg, D., and Karl, D.: Differences in the biological carbon pump at three subtropical ocean sites, Geophys. Res. Lett., 29, 1885, doi:1810.1109/2002GL015393, 2002.

Orcutt, K. M., Lipschultz, F., Gundersen, K., Arimoto, R., Michaels, A. F., Knap, A. H., and Gallon, J. R.: A seasonal study of the significance of $\mathrm{N}-2$ fixation by Trichodesmium spp. at the Bermuda Atlantic Time-series Study (BATS) site, Deep-Sea Res. Pt. II, 48, 1583-1608, 2001.

Oschlies, A.: NAO-induced long-term changes in nutrient supply to the surface waters of the North Atlantic, Geophys. Res. Lett., 28, 1751-1754, 2001.

Palter, J., Lozier, M., and Barber, R.: The effect of advection on the nutrient reservoir in the North Atlantic subtropical gyre, Nature, 437, 687-692, 2005.

Richardson, T. and Jackson, G.: Small phytoplankton and carbon export from the surface ocean, Science, 315, 838-840, 2007.

Riebesell, U., Schulz, K., Bellerby, R., Botros, M., Fritsche, P., Meyerhöfer, M., Neill, C., Nondal, G., Oschlies, A., Wohlers, J. and Zöllner, E.: Enhanced biological carbon consumption in a high $\mathrm{CO}_{2}$ ocean, Nature, 450, 545-548, 2007.

Riebesell, U., Wolf-Gladrow, D. A., and Smetacek, V.: Carbon dioxide limitation of marine phytoplankton growth rates, Nature, 361, 249-251, 1993.

Roman, M. R., Adolf, H. A., Landry, M. R., Madin, L. P., Steinberg, D. K., and Zhang, X.: Estimates of oceanic mesozooplankton production: a comparison using the Bermuda and Hawaii timeseries data, Deep-Sea Res. Pt. II, 49, 175-192, 2002.

Saba, V., Friedrichs, M. A. M., Carr, M.-E., Antoine, D., Armstrong, R., Asanuma, I., Aumont, O., Bates, N., Behrenfeld, M., Bennington, V., Bopp, L., Bruggeman, J., Buitenhuis, E., Ciotti, A., Doney, S., Dowell, M., Dunne, J. P., Dutkiewicz, S., Gregg, W., Hoepffner, N., Hyde, K., Ishizaka, J., Kameda, T., Lima, I. D., Lomas, M., Marra, J., McKinley, G., Melin, F., Moore, J., Morel, A., O’Reilly, J., Salihoglu, B., Scardi, M., Symth, T., Tang, S., Tjiputra, J., Uitz, J., Vichi, M., Waters, K., Westberry, T. K., and Yool, A.: The challenges of modeling depth-integrated marine primary productivity over multiple decades: A case study at BATS and HOT, Glob. Biogeochem. Cy., in review, 2010.
Schnetzer, A. and Steinberg, D.: Active transport of particulate organic carbon and nitrogen by vertically migrating zooplankton in the Sargasso Sea, Mar. Ecol-Prog. Series, 234, 71-84, 2002a.

Schnetzer, A. and Steinberg, D. K.: Natural diets of vertically migrating zooplankton in the Sargasso Sea, Mar. Biol., 141, 89-99, 2002b.

Siegel, D. A., Westberry, T. K., O’Brien, M. C., Nelson, N. B., Michaels, A. F., Morrison, J. R., Scott, A., Caporelli, E. A., Sorensen, J. C., Maritorena, S., Garver, S. A., Brody, E. A., Ubante, J., and Hammer, M. A.: Bio-optical modeling of primary production on regional scales: the Bermuda BioOptics project, Deep-Sea Res. Pt. II, 48, 1865-1896, 2001.

Sieracki, M., Verity, P. and Stoecker, D.: Plankton community response to sequential silicate and nitrate depletion during the 1989 North Atlantic spring bloom, Deep-Sea Res. Pt. II, 40, 213-226, 1993.

Steinberg, D., Lomas, M. W. and Madin, L. P.: A long-term increase in zooplankton biomass at the Bermuda Atlantic Timeseries Study (BATS) site in the Sargasso Sea, ASLO Ocean Sciences Meeting, Orlando, FL, Abstract 1976, 2008 a.

Steinberg, D., Van Mooy, B. A. S., Buesseler, K. O., Boyd, P., Kobari, T., and Karl, D.: Bacterial vs. zooplankton control of sinking particle flux in the ocean's twilight zone, Limnol. Oceanogr. 53, 1327-1338, 2008b.

Steinberg, D. K., Carlson, C. A., Bates, N. R., Goldthwait, S. A., Madin, L. P., and Michaels, A. F.: Zooplankton vertical migration and the active transport of dissolved organic and inorganic carbon in the Sargasso Sea, Deep-Sea Res. Pt. I, 47, 137-158, 2000.

Steinberg, D. K., Carlson, C. A., Bates, N. R., Johnson, R. J., Michaels, A. F., and Knap, A. H.: Overview of the US JGOFS Bermuda Atlantic Time-series Study (BATS): a decade-scale look at ocean biology and biogeochemistry, Deep-Sea Res. Pt. II, 48, 1405-1447, 2001.

Van Heukelem, L. and Thomas, C.: Computer-assisted highperformance liquid chromatography method development with applications to the isolation and analysis of phytoplankton pigments, J. Chromatogr. A, 910, 31-49, 2001.

Volk, T. and Hoffert, M. I.: Ocean carbon pumps: Analysis of relative strengths and efficiencies in ocean-driven atmospheric $\mathrm{CO}_{2}$ changes, in: The carbon cycle and atmospheric $\mathrm{CO}_{2}$ : natural variations Archean to Present, edited by: Sundquist, E. and Broecker, W., American Geophysical Union, Washington DC, 99-110, 1985.

Williams, P. J. 1. and Jenkinson, N.: A transportable microprocessor-controlled precise winkler titration suitable for field station and shipboard use, Limnol. Oceanogr., 27, 576-584, 1982. 